\title{
Analysis Pearson Correlation on National Broad Money (M2) and Deposit Distribution In Indonesia (case study : January 2006 - August 2016)
}

\author{
Hanif Novrandhita ${ }^{1)}$, Rosa Dzakiyyah ${ }^{2)}$ \\ ${ }^{1}$ Staff Operational at PT Bank Woori Saudara Indonesia 1906, Tbk Madiun Branch \\ ${ }^{2}$ Student at department Statistics, Islamic University of Indonesia \\ ${ }^{1}$ hanifnovrandhita@gmail.com, ${ }^{2} 15611163 @$ students.uii.ac.id
}

Article history:

Received April 23, 2017

Revised June 18, 2017

Accepted July 04, 2017

\section{Keywords:}

Pearson Correlation

Descriptive Statistics

National Broad Money

M2

Deposit Distribution

IDIC

Bank Indonesia

Indonesian Economic
The purpose of this research is to prove positive connection between circulation money (M2) with total of money which is secured in IDIC. This research data is coming from Bank Indonesia and IDIC website. This research is using analysis of pearson correlation and statistical analysis description. Result from this analysis is correlation between circulation money (M2) with total of money which is secured in IDIC as total as 0,99. From growth Yoy 2006-2014, circulation money years by years get up and down but on 2015-2016, circulation money get declining and this decline is not big decline.

\section{Introduction}

Indonesia has experienced periods of major economic crisis, the economic crisis that occurred in May 1998 was the cause of economic prices soared, rupiah exchange rate rupiah Rp. 2.000,00 per dollar up to Rp. $20.000,00$ or we call the devaluation of rupiah. Causing 16 banks liquidation to cause rush money, even BCA (Bank Central Asia) had experienced rush money. The money in a hurry is large and simultaneous cash. Rush Money because people worried that the bank was liquidation then they can't take the money in the savings. But thanks to government assistance, BCA which could get back to normal. Economic step by step after May 1998 become normal.

After May 1998, there were also several banks that merged into the government's objectives at that time. Example Namely Bank Bumi Daya, Bank Dagang Negara, Bank Ekspor Impor Indonesia, and Bank Pembangunan Indonesia into one bank, the bank Mandiri. Because of this economic crisis, the government also learn by forming an institution that guarantees the customer's money in order to remain a bank / financial institution.

A lesson for the banking industry including the government resulting from the monetary crisis in May 1998 to not happen again. Primarily to collect cash form a financial institution. So in 2004 the establishment of Lembaga Penjamin Simpanan (LPS) or IDIC (Indoneisa Deposit Insurance Corporation) in English.

Eventually, on 22 September 2004, the President of Republic of Indonesia enacted the Republic of Indonesia Law Number 24 concerning LPS. With regards to the law, LPS is established as an independent institution that functions to insure depositor's funds and actively participates in maintaining stability in the banking system in accordance with its authorized mandate. The Law 
effectively took effect on 22 September 2005 and IDIC officially began its operations as of that date.(www.LPS.go.id)

National Broad Money covers liabilities of monetary system (central bank, commercial and rural banks) to domestic private sector (excluding central government holdings of central bank liabilities other than currency and non- resident). Summary national broad money covers all the money circulation in society.

National Broad Money may be defined narrowly or broadly. Narrow broad money (M1) may be defined to include Currency Outside Commercial and Rural Banks and Demand Deposits denominated in Rupiah currency. Broader measure (M2) may cover M1, Saving Deposits, Time Deposits in Rupiah and foreign currency, Demand deposits in foreign currency and Securities other than shares issued by monetary system owned by domestic private sector, with remaining maturity up to 1 (one) year (www.BI.go.id).

The solution is information in deposit distribution in LPS must correlation with national broad money. In this section writer user Correlation Pearson Analysis In statistics, the value of the correlation coefficient varies between +1 and -1 .. As the correlation coefficient value goes towards 0 , the relationship between the two variables will be weaker. The most common measure of correlation in stats is the Pearson Correlation. The full name is the Pearson Product Moment Correlation or PPMC. It shows the linear relationship between two sets of data. Not Only Correlation, this correlation Analysis can be use in descriptive analysis statistics. Analysis data make data easy to understand everyone who read it.

So the paper divided in two section correlation using Pearson Correlation and descriptive analysis.

\section{Problems Formulations}

Pearson $r$ correlation: Pearson $r$ correlation is widely used in statistics to measure the degree of the relationship between linear related variables. Pearson $r$ correlation is used to measure the degree of relationship between the two commodities. The following formula is used to calculate the Pearson r correlation:

$$
r=\frac{\mathrm{N} \Sigma \mathrm{xy}-\Sigma(\mathrm{x})(\mathrm{y})}{\left.\sqrt{N \Sigma} x^{2}-\Sigma\left(x^{2}\right)\right]\left[N \Sigma y^{2}-\Sigma\left(y^{2}\right)\right]}
$$

Where:

$\mathrm{r}=$ Pearson $\mathrm{r}$ correlation coefficient

$\mathrm{N}=$ number of value in each data set

$\Sigma x y=$ sum of the products of paired scores

First Author et al. 4

$\Sigma \mathrm{x}=$ sum of $\mathrm{x}$ scores

$\Sigma y=$ sum of y scores

$\Sigma \times 2=$ sum of squared $\mathrm{x}$ scores

$\Sigma \mathrm{y} 2=$ sum of squared $\mathrm{y}$ scores

Assumptions For the Pearson $r$ correlation, both variables should be normally distributed. Other assumptions include linearity and homoscedasticity. Linearity assumes a straight line relationship between each of the variables in the analysis and homoscedasticity assumes that data is normally distributed about the regression line. The Pearson correlation coefficient, $r$, can take a range of values from +1 to -1 . A value of 0 indicates that there is no association between the two variables. A value greater than 0 indicates a positive association; that is, as the value of one variable increases, so does the value of the other variable. A value less than 0 indicates a negative association; that is, as the value of one variable increases, the value of the other variable decreases. This is shown in the diagram below: 


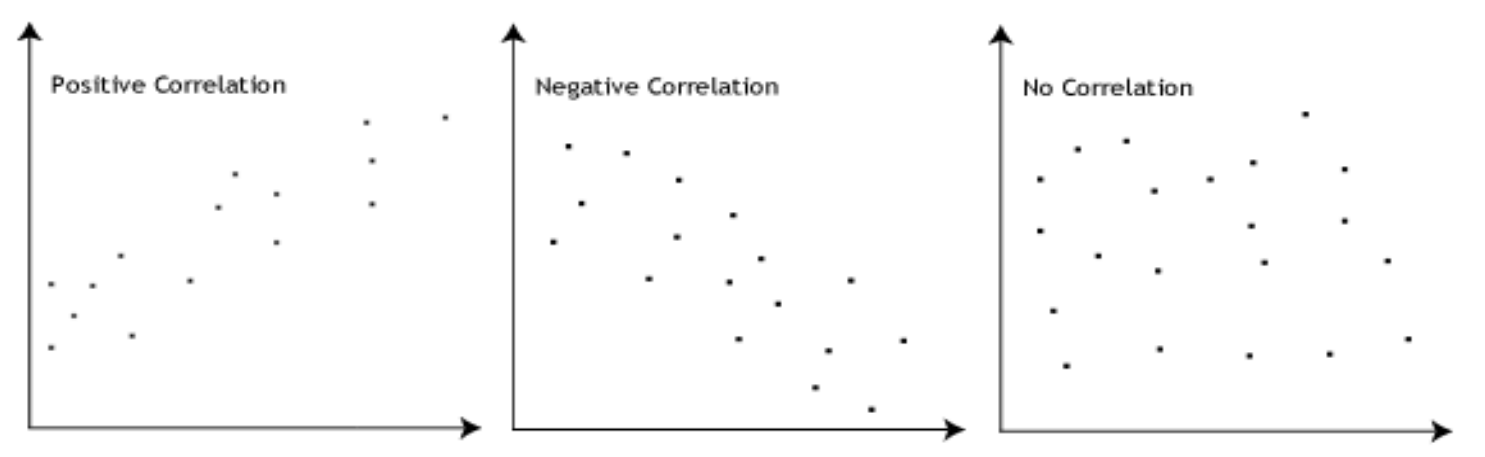

Fig. 1.Diagram

The stronger the association of the two variables, the closer the Pearson correlation coefficient, $r$, will be to either +1 or -1 depending on whether the relationship is positive or negative, respectively. Achieving a value of +1 or -1 means that all your data points are included on the line of best fit - there are no data points that show any variation away from this line. Values for $r$ between +1 and -1 (for example, $r=0.8$ or -0.4 ) indicate that there is variation around the line of best fit. The closer the value of $r$ to 0 the greater the variation around the line of best fit.

\section{A Step before the Final Submission}

The first we collect data as many as we can get, the first data from LPS, in distributed data LPS data only from January 2006, until August 2016. Then collect data with the time same as LPS from BI. After collect data, screening data is suitable with the paper.

First Variable about national broad money, second variable about information on deposit information. After collect data both variable, check normal distribution to the both variable.

Using Microsoft Excel. Both variable are normal, after data normal, analysis can be next step. Then descriptive analysis to the both variable and difference between two variable descriptive analysis. Settlement by making a Pearson correlation analysis.

\subsection{Headings and format}

Figures, tables, and equations.

Table 3.2.1. Sum of national board money and information on deposit distribution (in Billion)

\begin{tabular}{|c|c|c|c|c|c|c|c|c|c|c|c|c|}
\hline \multirow[b]{2}{*}{ month } & \multicolumn{2}{|c|}{2005} & \multicolumn{2}{|c|}{2007} & \multicolumn{2}{|c|}{2008} & \multicolumn{2}{|c|}{2009} & \multicolumn{2}{|c|}{2010} & \multicolumn{2}{|c|}{2011} \\
\hline & national broad & $\begin{array}{c}\text { information on } \\
\text { deposit } \\
\text { distribution }\end{array}$ & $\begin{array}{l}\text { national } \\
\text { broad money }\end{array}$ & $\begin{array}{c}\text { information on } \\
\text { deposit } \\
\text { distribution }\end{array}$ & national broad & $\begin{array}{l}\text { information } \\
\text { ondeposit } \\
\text { distribution }\end{array}$ & national broad & $\begin{array}{c}\text { information on } \\
\text { deposit } \\
\text { distribution }\end{array}$ & $\begin{array}{c}\text { national broad } \\
\text { money }\end{array}$ & $\begin{array}{l}\text { information } \\
\text { on deposit } \\
\text { distribution }\end{array}$ & national broad & $\begin{array}{c}\text { information on } \\
\text { deposit } \\
\text { distribution }\end{array}$ \\
\hline January & $1,194,939,00$ & $1,121,060,00$ & $1,367,957,00$ & $1,290,250,00$ & $1,596,565,00$ & $1,477,610,00$ & $1,874,145.25$ & $1,760,230,00$ & $2,073,859.77$ & $1,966,840,00$ & $2,436,678,95$ & $2,330,580,00$ \\
\hline February & $1,197,772,00$ & $1,128,420,00$ & $1,369,243,00$ & $1,293,000,00$ & $1,603,750,00$ & $1,481,430,00$ & $1,900,208.32$ & $1,783,740,00$ & $2,066,480,99$ & $1,948,440,00$ & 2,420,191,14 & $2,316,085,00$ \\
\hline March & $1,198,748,00$ & $1,128,110,00$ & $1,379,237,00$ & $1,298,410,00$ & 1,594,390,00 & $1,473,140,00$ & $1,916,752,36$ & $1,798,130,00$ & $2,112,182,70$ & $2,000,610,00$ & $2,451,356,92$ & $2,381,978,00$ \\
\hline April & $1,197,122,00$ & $1,127,010,00$ & 1,385,715,00 & $1,305,500,00$ & 1,611,691,00 & $1,488,200,00$ & $1,912,622,97$ & $1,791,610,00$ & $2,115,023,54$ & $1,999,150,00$ & $2,434,478,39$ & $2,368,030,00$ \\
\hline May & $1,241,865,00$ & $1,167,520,00$ & 1,396,057,00 & $1,310,970,00$ & 1,641,733,00 & $1,511,030,00$ & $1,927,069.54$ & $1,796,570,00$ & $2,143,234,05$ & $2,029,220,00$ & $2,475,285,98$ & $2,424,450,00$ \\
\hline June & $1,257,785,00$ & $1,175,510,00$ & $1,454,577,00$ & $1,356,640,00$ & 1,703,381,00 & $1,562,200,00$ & $1,977,532,44$ & $1,834,700,00$ & $2,231,144,33$ & $2,113,480,00$ & $2,522,783,81$ & $2,467,294,00$ \\
\hline July & $1,252,816,00$ & $1,168,050,00$ & $1,474,769,00$ & $1,380,740,00$ & $1,686,050,00$ & $1,542,730,00$ & $1,960,950,07$ & $1,820,080,00$ & 2, 2,17,,588,81 & 2,104,250,00 & $2,564556,13$ & $2,494,706,00$ \\
\hline August & $1,274,084,00$ & $1,193,960,00$ & $1,499,050,00$ & $1,396,590,00$ & 1,682,811,00 & $1,532,560,00$ & $1,995,294,18$ & $1,860,210,00$ & $2,236,459,45$ & $2,113,790,00$ & $2,621,345,74$ & $2,492,507,00$ \\
\hline September & $1,294,74,00$ & $1,121,420,00$ & 1,516,884,00 & $1,405,900,00$ & $1,778,139,00$ & $1,609,820,00$ & $2,018,510,30$ & $1,870,940,00$ & $2,274,954,57$ & $2,170,410,00$ & 2,643,331,45 & $2,586,980,00$ \\
\hline October & $1,329,425,00$ & $1,240,170,00$ & $1,533,846,00$ & $1,424,760,00$ & 1,812,450,00 & $1,682,900,00$ & 2,021,517,32 & $1,877,600,00$ & $2,308,845.97$ & $2,201,830,00$ & $2,677,786,93$ & $2,625,158,00$ \\
\hline November & $1,341,940,00$ & $1,259,980,00$ & 1,559,570,00 & $1,433,160,00$ & $1,851,023,00$ & $1,715,800,00$ & $2,062,206.27$ & 1,913,650,00 & $2,347,806,86$ & $2,241,790,00$ & 2,729,538,27 & 2,684,747,00 \\
\hline December & $1,382,493,00$ & $1,297,860,00$ & $1,649,652,00$ & $1,520,150,00$ & $1,895,839,00$ & $1,768,620,00$ & 2,141,333,70 & 1, $, 995,790,00$ & $2,471,205,79$ & $2,370,980,00$ & 2,877,219,57 & $2,830,323,00$ \\
\hline
\end{tabular}


Table 3.2.2. Sum of National Board Money and Information on Deposit Distribution ( on Billion)

\begin{tabular}{|c|c|c|c|c|c|c|c|c|c|c|}
\hline \multirow[b]{2}{*}{ month } & \multicolumn{2}{|c|}{2012} & \multicolumn{2}{|c|}{2013} & \multicolumn{2}{|c|}{2014} & \multicolumn{2}{|c|}{2015} & \multicolumn{2}{|c|}{2016} \\
\hline & $\begin{array}{c}\text { national broad } \\
\text { money } \\
\end{array}$ & $\begin{array}{c}\text { information } \\
\text { on deposit } \\
\text { distribution }\end{array}$ & national broad & $\begin{array}{c}\text { information } \\
\text { on deposit } \\
\text { distribution }\end{array}$ & national broad & $\begin{array}{c}\text { information on } \\
\text { deposit } \\
\text { distribution }\end{array}$ & national broad & $\begin{array}{c}\text { information on } \\
\text { deposit } \\
\text { distribution }\end{array}$ & broad money & $\begin{array}{c}\text { information on } \\
\text { deposit } \\
\text { distribution }\end{array}$ \\
\hline January & $2,857,126.93$ & $2,812,389,00$ & $3,307,507,55$ & $3,253,000,00$ & $3,730,409.35$ & $3,637,382,00$ & $4,174,825.91$ & $4,168,841,00$ & $4,498,361.28$ & $4,468,860,00$ \\
\hline February & $2,852,004,94$ & $2,809,349,00$ & $3,268,789.15$ & $3,265,247,00$ & $3,635,060,38$ & $3,651,574,00$ & $4,218,122,76$ & $4,222,482,00$ & $4,521,951,20$ & $4,512,757,00$ \\
\hline March & $2,914,194,47$ & $2,879,534,00$ & $3,280,420,25$ & $3,307,495,00$ & $3,652,530,55$ & $3,671,553,00$ & $4,246,361,19$ & $4,279,063,00$ & $4,561,872,52$ & $4,550,907,00$ \\
\hline April & $2,929,610,37$ & $2,894,013,00$ & $3,322,528,96$ & $3,360,138,00$ & $3,721,882,38$ & $3,749,915,00$ & $4,275,711,11$ & $4,305,689.00$ & $4,581,877,87$ & $4,562,449,00$ \\
\hline May & $2,994,474,39$ & $2,958,972,00$ & $3,360,928.07$ & $3,399,580,00$ & $3,780,955.28$ & $3,822,525,00$ & $4,288,369.26$ & $4,327,966,00$ & $4,614,061.82$ & $4,589,453,00$ \\
\hline June & $3,052,786,10$ & $3,010,181,00$ & $3,426,304,92$ & $3,434,159,00$ & $3,857,961,77$ & $3,889,318,00$ & $4,358,801.51$ & $4,411,687,00$ & $4,737,451.23$ & $4,678,284,00$ \\
\hline July & $3,057,335.75$ & $3,011,850,00$ & $3,413,378,66$ & $3,447,375,00$ & $3,887,407,48$ & $3,828,767,00$ & $4,373,208,10$ & $4,415,367,00$ & $4,730,379,68$ & $4,661,705,00$ \\
\hline August & $3,091,568.49$ & $3,037,803,00$ & $3,506,573,60$ & $3,496,756,00$ & $3,886,519,97$ & $3,910,281,00$ & $4,404,085,03$ & $4,451,403,00$ & $4,745,017,13$ & $4,678,284,00$ \\
\hline September & $3,128,179.27$ & $3,104,251,00$ & $3,502,419.80$ & $3,599,133,00$ & $4,010,146,66$ & $4,062,918.00$ & $4,508,603,17$ & $4,546,948,00$ & & \\
\hline October & $3,164,443,15$ & $3,119,552,00$ & $3,584,080,54$ & $3,574,573,00$ & $4,024,488.87$ & $4,084,023,00$ & $4,443,078,08$ & $4,454,912,00$ & & \\
\hline November & $3,207,908.29$ & $3,182,867,00$ & $3,576,869,35$ & $3,617,855,00$ & $4,076,669.88$ & $4,124,111,00$ & $4,452,324,65$ & $4,452,224,00$ & & \\
\hline December & $3,307,507,55$ & $3,277,154,00$ & $3,616,049,20$ & $3,706,609,00$ & $4,173,326.50$ & $4,165,300,00$ & $4,548,800.27$ & $4,473,772,00$ & & \\
\hline
\end{tabular}

From Table 3.2.1 and 3.2.2.

Both variable sum of national broad money and information on deposit distribution (in Billion) from year 2006 until 2016 always increase, this is due to increase from Net Foreign Assets (NFA), Net Domestic Assets (NDA) every year.

Both Variable, Variable sum of national December 2006 (1,382,493.00) to December 2007 $(1,049,062.00)$ to December $2008(1,895,839.00)$ and always increase Year by Year until August 2016 $(4,745,017.13)$, Variable information on deposit distribution in December $2006(1,297,800.00)$ to December $2007(1,520,150.00)$ to December $2008(1,895,839.00)$ and always increase year by Year until August $2016(4,678,284.00)$.

But to see increase from month to month, not every month both variable always increase, sometimes both variable decrease. Decrease often after ied fitri, for example in 2016 decrease from June to July, from the variable sum of national broad money from June $(4,737,451.23)$ to July $(4,730,379)$ and from variable information on deposit information June $(4,678,284.00)$ to July $(4,661,705.00)$. In 2015 too, from Variable sum of National broad Money, September $(4,508,603.17)$ to October $(4,443,078.08)$.

Before to next step, make sure both variable national broad money and information on deposit distribution are normal distribution with level confidence $95 \%$.

a. Variable national broad money

$\mathrm{Z}$ count with maximum value 1.85 and minimum value (1.39), value table $\mathrm{z}$ with count 128 is 1,96 so $\mathrm{z}$ count $>\mathrm{z}$ table, from the statement Variable national broad money is normal distribution

b. Variable Information on deposit distribution

$\mathrm{Z}$ count with maximum value 1.76 and minimum value (1.34), value table $\mathrm{z}$ with count 128 is 1,96 so $\mathrm{z}$ count $>\mathrm{z}$ table, from the statement Variable national broad money is normal distribution

\section{Labels 3.2.1. Labels of figures and tables}

Writer in here, make another descriptive analysis About Growth Year on Year (Yoy) national broad money and information on deposit distribution (in percent). 
Table 3.2.1.1. Growth (yoy) national board money and information on deposit distribution (in percent)

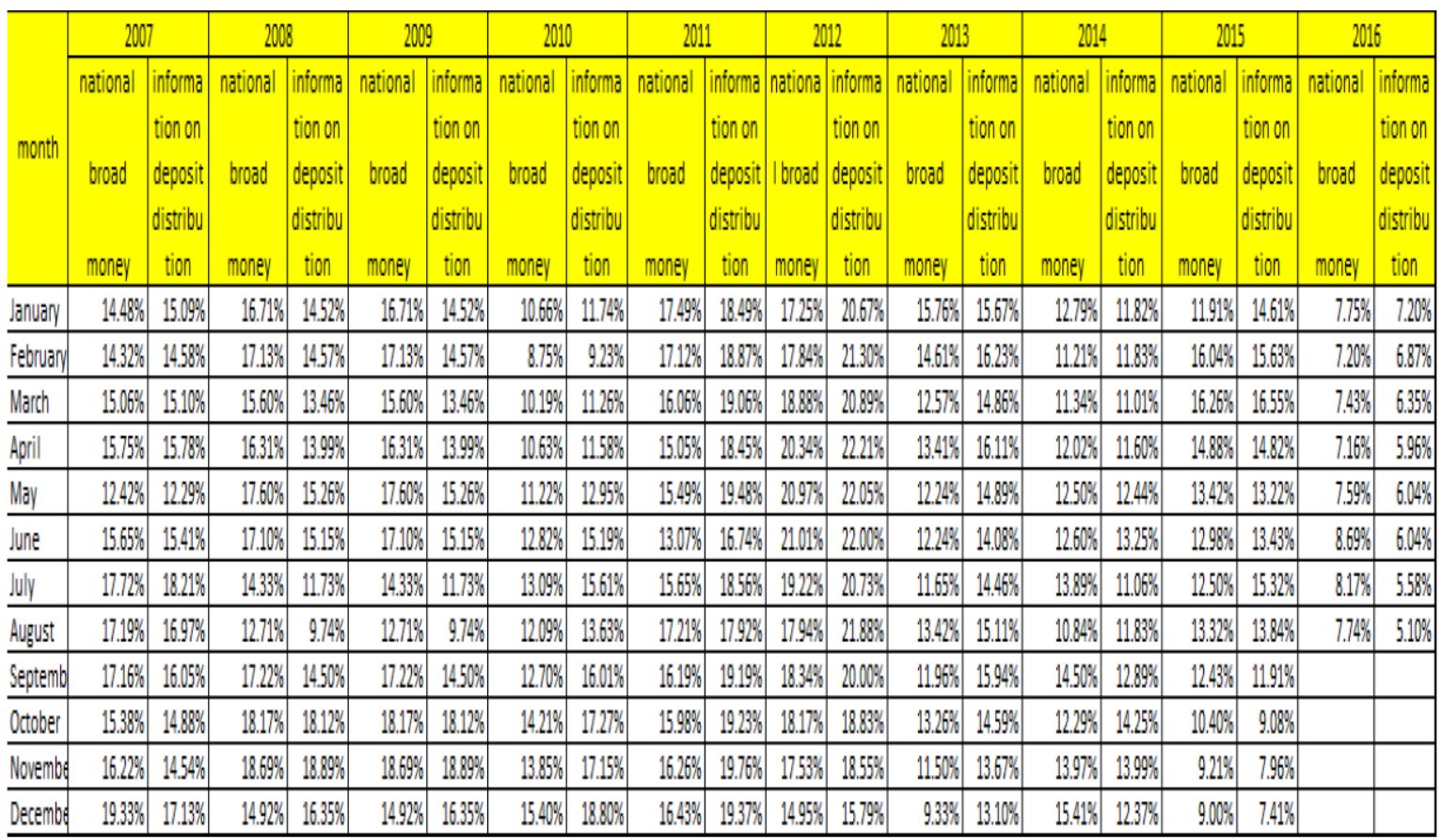

\section{Growt (Yoy) national broad money with deposit distribution}

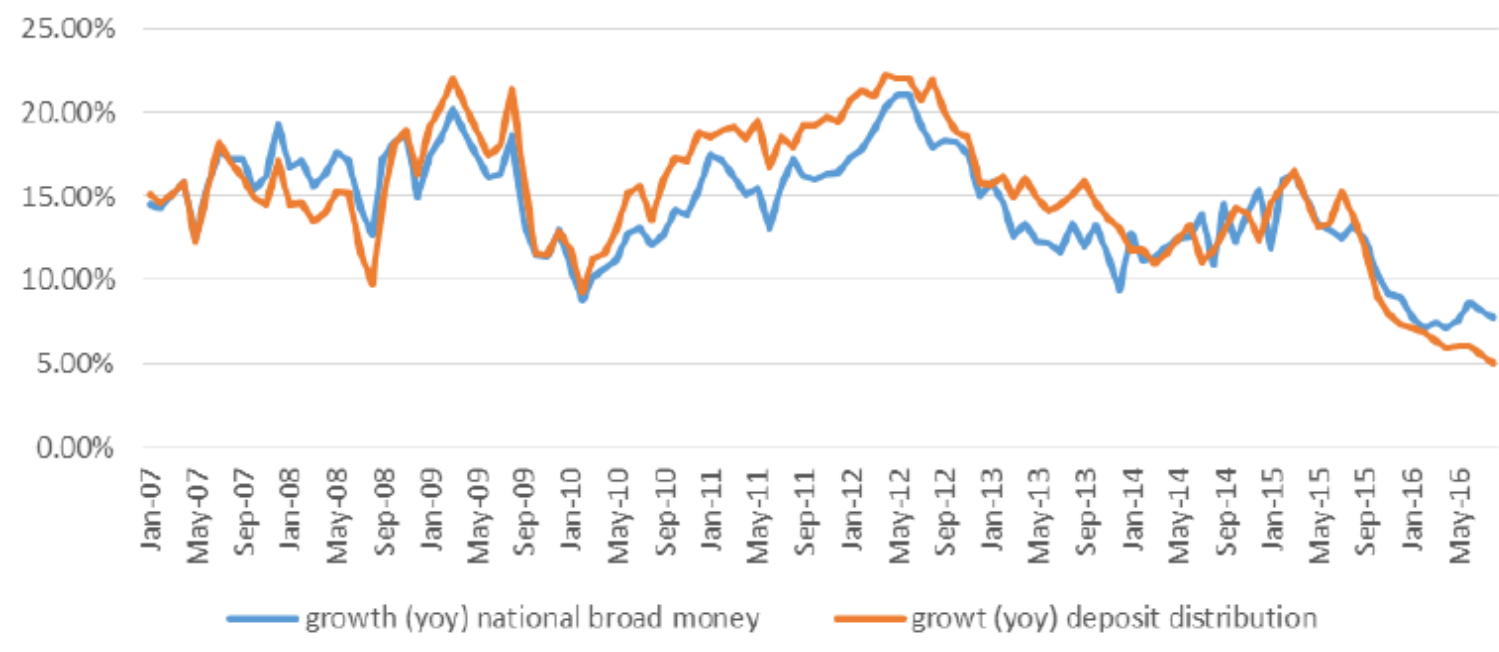

Fig. 3.2.1.2

Growth Yoy 2006-2014, circulation money years by years get up and down but on 2015-2016, circulation money get declining and this decline is not big decline. From this data, Indonesian Economic Development also in negative point, that's make government many policy economy to help Indonesian Economic Development in Positive Point such as tax amnesty. Moratorium CPNS (Calon Pegawai Negeri Sipil), Moratorium expansion regional and etc. 


\section{Compare national broad money with information on deposit distribution (in billion)}

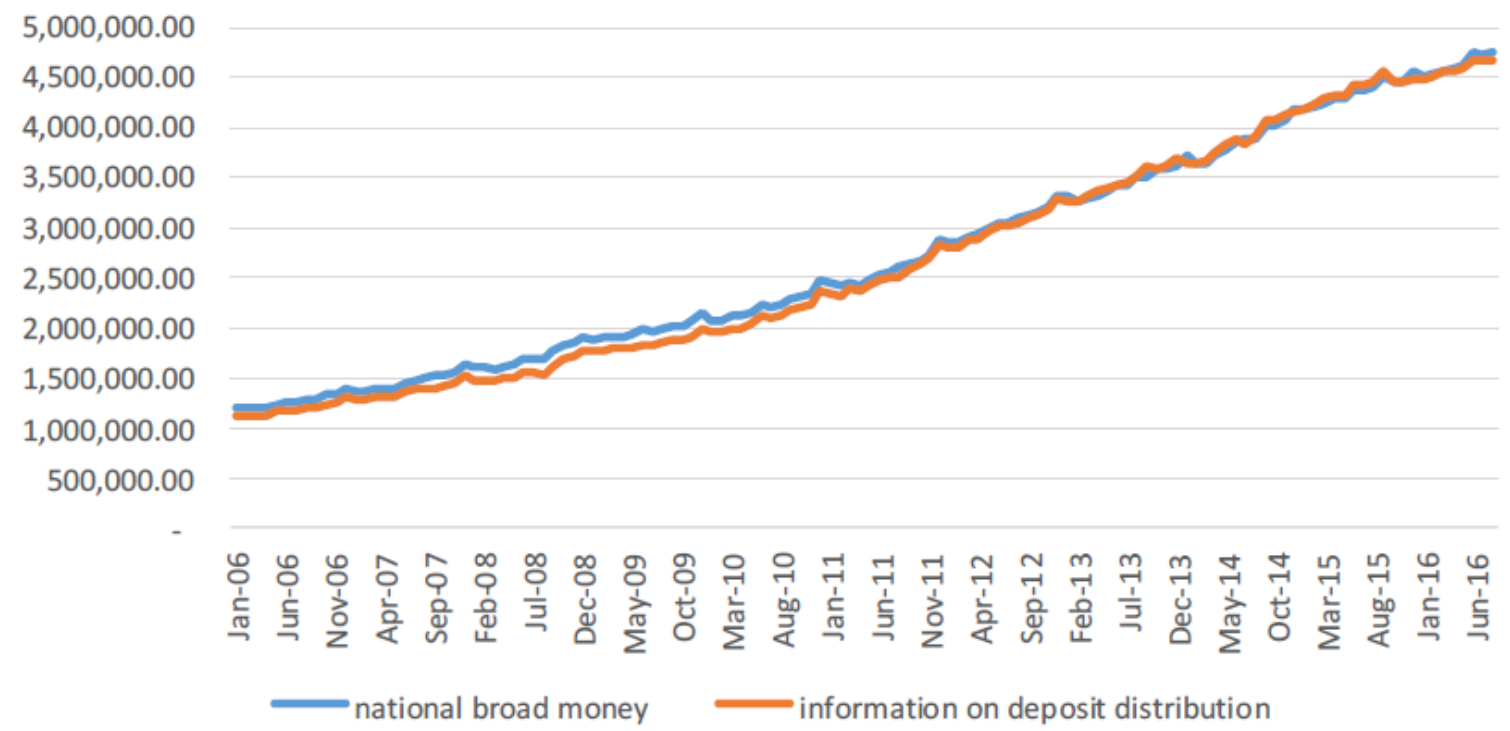

Fig. 3.2.1.3

From This Graphic Compare national broad money with information on deposit distribution (in billion). Both Variable national broad money and information on deposit distribution have the same development. From graphic writer also make correlation analysis with the result 0,99. It means correlation almost perfect because more than 0,9 .

\section{Conclusion}

Data Presented from national broad money and information on deposit distribution in Rupiah and USD. Data Include under data from Indonesia Government through Independent institutions Bank Indonesia (BI) and Indonesia Deposit Insurance Corporation (IDIC). Data presented from January 2006 (2 months after IDIC was established) until now (august 2006). Data From Bank Indonesia is Sum of National Broad Money or M2 and Data from IDIC sum of information on deposit distribution

Both variable national broad money and information on deposit distribution must correlation about $0,8-1$. To answer system Banking in Indonesia until Now is saving. That's why IDIC was established by Indonesian Government. Graphic also support both variable are correlation. As the information, both national broad money and Information on deposit distribution are always increase year by year. Presented to Graphic from Year on Year from both variable, From Growth Year on Year always increase too year by year or called YoY.

In Every Year, national Broad Money always increase, it cause increase net foreign asset and net domestics asset. The Development from national broad money always increase year by year but detail month by month, trend data from Indonesia, decrease always when ied fitri (the biggest day to Muslim Indonesia). Example on 2016 decrease from June 2016 to July 2016. Conclusion from the main discussion is value of correlation Pearson is 0,99 . So far so excellent compare about national broad money and deposit information. And system banking Indonesia is save until now. The society don't afraid about system bank now specially to save some money to bank in Indonesia, because correlation 0,99 it means almost perfect. It means if one of bank in Indonesia liquidities, money customer in the bank save, not liquidity like that bank.

\section{Open Problem}

The problem is why the data LPS is many bigger than national broad money from 128 data. such as in average 2013 and 2015. Supposedly variable national broad money many more than variable information on deposit distribution in IDIC but some data in variable national broad money less more 
than information on deposit distribution in IDIC, because the rules IDIC deposit distribution single customer on single bank could be guaranteed a maximum of 2 Billion for the rupiah (USD based on exchange rate) with Interest Rate 6:25 for rupiah and USD rate of 0.75 for the period (September 15, 2016 until January 2017)

For more complex analysis, next paper should be input other variable. From www.BI.go.id The Affecting Factors of Broad Money or Broad Money Liabilities equal to the sum of Net Foreign Assets (NFA), Net Domestic Assets (NDA) and net other items. NDA measure covers Net Claims on Central Government (NCG) and Other Claims (i.e. Local Government, Other Financial Corporations, NonFinancial Corporations and Households) mainly in the form of Loans.

Broad money and Its affecting factors are compiled based on Monetary and Financial Statistics Manual (MFSM) 2000 and Compilation Guide (2008). Writer suggestion inflation can be input other variable too. Example analysis can be regression or analysis time series. Can probability if happen crisis money again in Indonesia like happened in May 1998. In Other section customer can choose bank with LPS Label. Because LPS only insurance bank suitable with LPS Society. Bank in Indonesia must Under LPS. But sometime there some money save in bank not suitable with LPS society. Like interest rate LPS more high than interest rate LPS. So customer if want to save money must prudent.

\section{Acknowledgment}

Appreciation for Bank Indonesia and Lembaga Penjaminan Simpanan (also IDIC in English) for make report every year, Pearson for making analysis Pearson Correlation and everyone who make the report publication for free to every stakeholder.

\section{References}

[1] www.bi.go.id ; http://www.bi.go.id/id/statistik/seki/terkini/moneter/Contents/Default.aspx last visit on 31 October 2016. http://www.bi.go.id/id/publikasi/perkembangan/Default.aspx last visit on 31 October 2016.

[2] www.lps.go.id ; http://www.lps.go.id/web/guest/sejarah last visit on 31 October 2016. http://www.lps.go.id/web/guest/data-distribusi-simpanan last visit on visit 31 October 2016.

[3] http://repository.widyatama.ac.id/xmlui/bitstream/handle/123456789/3089/Bab\%202.pdf?sequence=7 last visit on 30 October 2016

[4] http://www.statstutor.ac.uk/resources/uploaded/pearsons.pdf last visit on 30 October 2016.

[5] http://www.statisticshowto.com/what-is-the-pearson-correlation-coefficient/last visit on 29 October 2016

[6] https://statistics.laerd.com/statistical-guides/pearson-correlation-coefficient-statistical-guide.php Last Visit On 31 October 2016.

[7] http://www.statisticssolutions.com/correlation-pearson-kendall-spearman. 